\title{
$5-1986$
}

\section{Forensic Social Work: Practice and Vision}

Thomas P. Brennan

Circuit Court of of Cook County, Chicago

Amy E. Gedrich

Circuit Court of Cook County, Chicago

Michael J. Tardy

Circuit Court of Cook County, Chicago

Katherine Tyson McCrea

Loyola University Chicago, ktyson@luc.edu

Follow this and additional works at: https://ecommons.luc.edu/socialwork_facpubs

Part of the Social Work Commons

\section{Recommended Citation}

Brennan, Thomas P., Amy E. Gedrich, Susan E. Jacoby, Michael J. Tardy, Katherine Tyson McCrea. "Forensic Social Work: Practice and Vision." Social Casework, vol. 67, no. 6 (1986): 340-350.

This Article is brought to you for free and open access by the Faculty Publications and Other Works by Department at Loyola eCommons. It has been accepted for inclusion in Social Work: School of Social Work Faculty Publications and Other Works by an authorized administrator of Loyola eCommons. For more information, please contact ecommons@luc.edu.

\section{c) (i) $\Theta$}

This work is licensed under a Creative Commons Attribution-Noncommercial-No Derivative Works 3.0 License. (C) 1986 Family Service America. 


\section{Thomas P. Brennan, Amy E. Gedrich, Susan E. Jacoby, Michael J. Tardy, and Katherine B. Tyson Forensic Social Work:
Practice and Vision}

Forensic social work can bridge the gap between the criminal justice and mental health systems and serve clients who "fall between the cracks." The authors describe theoretical and clinical issues, utilizing case examples and the literature to develop a conceptual paradigm for the role of social workers in this area.

Thomas P. Brennan is Assistant Director, Amy E. Gedrich and Susan E. Jacoby are Court Caseworkers, and Michael J. Tardy is District Supervisor, Social Service Department, Circuit Court of Cook County, Chicago, Illinois. Katherine B. Tyson is a Psychiatric Social Worker, Olympia Fields Osteopathic Medical Center, Olympia Fields, Illinois.

THE GAP BETWEEN THE criminal justice and mental health systems has existed for some time; thus twenty years ago, Karl Menninger lamented and criticized the "cold war between lawyers and psychiatrists." The gap has been created by many factors, among them differences in history, tradition, philosophy, semantics, and societal mandates. Although to some extent it is important that the criminal justice and mental health systems remain practically and conceptually distinct, there are times when the conflicts between the two systems persist at great cost to individual and social well-being. ${ }^{2}$

Many defendants come before the court as a result of actions symptomatic of psycho-

1. Karl Menninger, The Crime of Punishment (New York: The Viking Press, 1968).

2. Irving R. Kaufman, "The Insanity Plea on Trial," New York Times Magazine, 8 Aug. 1982, 16-20; Harold A. Levine, "Countertransference Reactions in the Evaluation and Treatment of Court-Ordered Patients," Bulletin of the Menninger Clinic 46 (July 1982):352-62; Ner Littner, "The True Test of Criminal Responsibility" (Panel presentation to the Illinois Academy of Criminology, Chicago, Illinois, October 20, 1982); and James Pearre and Charitey Simmons, "Mentally Ill or Well? Question Becomes Increasingly Troublesome to Society," Chicago Tribune, 29 Nov. 1976, section 1. social distress. For example, several studies have reported that the rise of criminal behavior by ex-mental patients is the result of their release into the community without adequate resources. ${ }^{3}$ Some defendants considered "untreatable" within the mental health system, as it exists now, often combine such problems as substance abuse, indigence, and chronic, severe psychopathology. They present themselves to mental health personnel as poor candidates for treatment. In addition, individuals who once were able to function fairly well may have regressed when deprived of a job or adequate social supports. Not recognizing their difficulties as amenable to treatment, they do not seek help but may manifest their desperation in such minor criminal behaviors as traffic offenses or shoplifting. Finally, the pathology of some patients who are receiving treatment may make predicting or forestalling violent behavior difficult, as with the Vietnam War veteran who becomes violent only during flashbacks.

These types of defendants often turn up in handcuffs before a judge who recognizes that, without adequate treatment, they will be before the court again, having hurt someone else or themselves once more. Sentencing

3. Marc F. Abramson, "The Criminalization of Mentally Disordered Behavior: Possible Side-Effect of a New Mental Health Law," Hospital and Community Psychiatry 23 (April 1972):101-05; and Gary E. Whitmer, "From Hospitals to Jails: The Fate of California's Deinstitutionalized Mentally Ill," American Journal of Orthopsychiatry 50 (January 1980):65-75. 
them to jail protects the community temporarily. However, jail can result in the defendant's suicide 4 or eventual release with the most antisocial aspects of his or her character strengthened by the effort to survive incarceration.

Such costly results of imprisonment raise a question: Are there other ways of handling these defendants that will combine the goals of treatment and justice? In "The Development of Forensic Social Work," Gary Whitmer" noted, with hope, that forensic social work can begin to bridge the gap between the criminal justice and mental health systems and can serve clients, such as those just mentioned, who are "forfeited" by this gap. Whitmer defined the forfeited client as the former long-term hospitalized individual released to the community who has "not been passively lost to treatment programs; on the contrary, mental health professionals have actively struggled with these patients' problems but have acknowledged defeat." The authors of this article define the term somewhat more broadly, to encompass any individual with an emotional or a mental disorder, or both, who has become "lost" in the mental health system or whose needs cannot be met within this system. They are patients who cannot be treated through current outpatient practices, because they refuse treatment, and who do not meet the criterion of dangerousness to self or to others, and hence cannot be hospitalized. This combination of programmatic, clinical, and legal factors has helped create the forfeited client.

The goal of this article is to affirm Whitmer's presentation and to provide a conceptual paradigm for forensic social work by describing the major theoretical and clinical aspects of forensic social work as practiced at the Social Service Department ${ }^{7}$ of the Circuit Court of Cook County, State of Illinois.

4. Lindsey Gruson, "The Problems of Mental Illness Are Compounded Behind Bars," New York Times, 23 Jan. 1983.

5. Gary E. Whitmer, "The Development of Forensic Social Work," Social Work (May-June 1983):217-22.

6. Ibid., p. 217.

7. Thomas P. Brennan and Violet Park, "The Role of the Social Service Departments in the Court System," Judicial Administration Newsletter 7 (February 1977).
The literature from the fields of social work, criminal justice, and psychiatry is drawn on to develop the theoretical base for forensic social work; case studies are presented to demonstrate the varied roles of the forensic social worker.

\section{Theoretical Perspectives}

The Social Service Department's mandate is single-minded-to serve the court. The workers' role has two polarized dimensions: a social work function and a law enforcement or control function. The polarities of casework and control are essential and have their basis in the department's budget appropriation, ${ }^{8}$ in the criminal statutes, ${ }^{9}$ in court, and in the authors' experiences. Fulfilling this mandate, the department integrates the goals and services of mental health and criminal justice.

The ideal of the department is to form a worker-defendant relationship ${ }^{10}$ and, as a result, to facilitate growth so that the defendant

8. The Cook County Government sponsors the "Protection of Persons and Property" program, which funds the Social Service Department through the Judicial Administration to provide social casework service. Two goals of the program are most congruent with the department's goals: to provide maximum security and to assist in rehabilitation. See The Annual Appropriation Bill for the fiscal year of 1983 approved and adopted February 28, 1983, by George W. Dunne, President, Cook County Board of Commissioners.

9. The department's function is to provide service to court-referred misdemeanor cases. Cases are referred either because defendants are placed on supervision or sentenced to conditional discharge, usually for one year. The statutes view supervision and conditional discharge as opportunities for rehabilitation-in the supervision order or conditional discharge sentence, the defendant is ordered to report in person to his or her caseworker and to comply with other conditions the court may see as facilitating rehabilitation. The department's chief control function lies in returning cases to court for a hearing if defendants do not cooperate with the court order or are convicted of another of fense. Defendants, whether placed on supervision or sentenced to conditional discharge, are found guilty. If the conditions are fulfilled, the supervision order will not result in a conviction and consequent criminal record. The conditional discharge sentence is a conviction and does result in a criminal record (Illinois Revised Statutes-198I: State Bar Association, Ed., Ch. 38: 1005-6-3- and Ch. 38:1005-6.1. St. Paul, MN: West Publishing Co., 1982).

10. Social casework service is the formation of a casework relationship within a problem-solving context: the dynamic interaction of feelings and attitudes between caseworker and defendant. The caseworker's purpose is to help the defendant make a better, lawful adjustment to his or her environment. The caseworker may provide 
can meet his or her needs legally. It is the authors' belief that, insofar as the goals of mental health are striven for, the goals of criminal justice will be fulfilled. In other words, the authors do not believe that a conflict between the goals of mental health and the goals of criminal justice is inevitable. The control function in the context of the department is, in part, to monitor: to contact the defendant or collateral from an outreach frame of reference in order to acquire information to seek the defendant's whereabouts, to help defendants keep appointments, to acquire criminal history information to check new arrests or convictions or both, and to bring the case to the attention of the court if the court order is violated.

Since the hallmark of the department is to form a relationship with the defendant, the department necessarily espouses casework as its ideal. To place the concept casework in a broader perspective, it is one of two generic types of service that have developed in the field of corrections; the other is brokerage." Claude T. Mangrum placed casework in the context of "coercive casework in corrections."12 Casework can be defined essentially as the development of a relationship between worker and client, within a problem-solving context, and coordinated with the appropriate use of community resources. Brokerage can be defined as the process of recognizing individual needs, matching a community resource to meet those needs, and making a referral. The essential difference is one of depth and emphasis: casework emphasizes the relationship and direct service; brokerage emphasizes community resources. In the authors' experiences, the casework approach is more effective at helping the client resolve the problems that led to criminal behavior. However, casework

direct, supportive-confrontative service or make a referral to an appropriate resource. The treatment plan is based on the defendant's needs and the caseworker's skills and available time. In addition to sessions in the caseworker's office, field visits are often conducted with defendants and their families or other supportive agencies.

11. Frank Dell 'Apa, "Advocacy, Brokerage, Community: The ABC's of Probation and Parole," Federal Probation xxxx (December 1976).

12. Claude T. Mangrum, "The Function of Coercive Casework in Corrections," Federal Probation xxxv (September 1971). is not possible in many correctional agencies. ${ }^{13}$

The forensic social worker role has two aspects: providing treatment and protecting the community. Although these two aspects often complement each other, there are times when they can be experienced as conflicting and mutually exclusive. For example, protecting the community can seem opposed to providing for the client's welfare, and monitoring can seem opposed to respecting the client's right to self-determination. The following theoretical perspectives define the role of the forensic social worker to recognize and to integrate the goals of criminal justice and mental health.

Thomas L. Shaffer ${ }^{14}$ succinctly conceptualized the polarity as a difference in training between lawyers and counselors by stating that few lawyers would become good counselors and that few counselors would become good lawyers-"Because a lawyer's training stresses aggression and order and a counselor's training emphasizes acceptance and understanding." Lawyers are trained to view human facts in terms of their relevance, consequences, and accuracy. Counselors are trained to assess human facts in relation to feelings, considering their implications for relationships and individual well-being. Shaffer suggested that the two dimensions-one a thinking dimension and the other a feeling dimensionare both necessary and have much to offer each other.

In terms of style, Louis Tomaino and Arthur Spica's both discussed the role and function of a probation officer and have based their perspectives on Robert J. Blake and Jane S. Mouton's managerial grid!6 Spica

13. Brokerage has been the modality used by many departments because personnel are not "equipped by education and experience to provide casework counseling...." because manpower resources are low, and because caseloads are high. See Dell 'Apa, "Advocacy, Brokerage, Community," p. 38.

14. Thomas L. Shaffer, "Lawyers, Counselors, and Counselors at Law," American Bar Journal 61 (July 1975):854-56.

15. Louis Tomaino, "The Five Faces of Probation," Federal Probation xxxix (December 1974):42-45; and Arthur Spica, "The Correctional Novagram," Federal Probation xxxix (December 1977):47-51.

16. Robert J. Blake and Jane S. Mouton, The Managerial Grid: Key Orientation for Achieving Production Through People (Houston, TX: Gulf Publishing Co., 1964). 
contrasted the bureaucratic function with the relationship function, stating that the probation officer "must satisfy the rules of the court, the law enforcement agencies, the legal profession, the community, and the standards of the particular agency. On the other hand, the needs of the offender, that is the psychological, physical, social developmental, and rehabilitative needs must be met." He synthesized the bureaucratic and relationship function through the concept of a "resource integrator," a worker who establishes a firm but understanding relationship.

In The Skilled Helper, Gerard Egan" presented a model for skills training, developing his skill definitions from Robert R. Carkhuff. ${ }^{18}$ Accurate empathy and confrontation are among the skills presented, skills that correspond to the polar functions of the forensic social worker's role. Accurate empathy is defined as understanding the frame of reference of the client and communicating this understanding in terms of feeling, experience, and behavior. Egan presented empathy as the core skill of his model. He defined confrontation as

responsible unmasking of the discrepancies, distortions, games, and smoke screens the client uses to hide both from self-understanding and from constructive behavioral change. . involves challenging the undeveloped, the underdeveloped, the unused, and the misused potentialities, skills, and resources of the client, with a view to examining and understanding these resources and putting them to use in action problems....

Although most counselors understand, use, and experience confrontation as opposed to empathy, Egan contended that effective confrontation is really an extension of empathy.

Although the psychoanalytic tradition does not speak directly to the dual role of the forensic social worker, it contributes valuable insights into the treatment of forfeited and antisocial clients. ${ }^{19}$ August Aichhorn, in de-

17. Gerard Egan, The Skilled Helper: A Model for Systematic Helping and Interpersonal Relating (Monterey, CA: Brooks/Cole Publishing Co., 1976).

18. Robert R. Carkhuff, Helping and Human Relations, Vol. I: Selections and Training, Vol. II: Practice and Reseanch (New York: Holt, Rinehart, and Winston, 1969).

19. Adelaide M. Johnson and S.A. Szurek, "The Genesis of Antisocial Acting Out in Children and Adults," scribing empathic treatment of "wayward youth," stated that "psychoanalysis enables the worker to recognize dissocial manifestations as the result of an interplay of psychic forces, to discover the unconscious motives of such behavior, and to find means of leading the dissocial back to social conformity." 20 He was able to apply psychodynamic principles to treat the openly resistive, socially deprived clients seen by the forensic social worker. $\mathrm{He}$ also noted that, even in timelimited treatment, he could assess and facilitate ego functioning. The challenge to the forensic social worker is to implement the insights of psychoanalysis within the context of the authority of the court.

The resolution of the treatment and control polarities necessarily has to occur within the individual worker who comes to integrate both dimensions, recognizing and accepting the creative tension between them. This calls for a skilled helper, an artist, a person who has the capacity to be both empathic and confrontative depending on the needs of the client and the community. Figure 1 integrates the various polarities as described by Shaffer, Tomaino, Spica, Blake and Mouton, and Egan. ${ }^{21}$

Practically, the Social Service Department serves the court and, as a result, is not in a position to control its intake by informing the court that its caseloads are full. To help structure its resources, the department developed a classification instrument (caseload management assessment). The instrument is comprised of thirteen factors (for example, prior arrests, support system, employment and residence stability, mental health, substance abuse) based on the defendant's needs. These factors are believed to predict the defendant's likelihood of reentering the criminal justice system. They also relate to the amount

Psychoanalytic Quarterly xxi (1952):323-43; August Aichhorn, Waywand Youth: A Psychoanalytic Study of Delinquent Children (New York: Meridian Books, 1962); and Otto Fenichet, "Perversions and Impulse Neurosis" and "Character Disorders," in The Psychoanalytic Theory of Neurosis (New York: Norton, 1945).

20. Aichhorn, Wayward Youth, p. 1.

21. Shaffer, "Lawyers, Counselors, and Counselors at Law"; Tomaino, "The Five Faces of Probation"; Spica, "The Correctional Novagram"; Blake and Mouton, The Managerial Grid; and Egan, The Skilled Helper. 
of time required for contact, since every defendant does not require the same amount of time. The instrument thus serves to guide caseworkers in structuring their time. In addition to this instrument, other forms of assessment, knowledge of resources, and supportive supervision with goals of case management and prevention of burn-out are essential tools for caseload management.

\section{Case Presentations}

The following case examples illustrate the types of clients referred to forensic social workers and the major issues involved in assessment and treatment.

\section{Modification of Traditional Treatment Arrangements}

Forensic social workers are often called on to work with clients who, for various reasons, have been unable to profit from a treatment alliance with therapists in other settings. Thus it becomes essential that the forensic social worker assess the client's potential for utilizing treatment and arrange the treatment contract to maximize benefits for the client. ${ }^{22}$ The case below points up the need to structure treatment based on an assessment of the client's needs and capacity to respond to treatment.

Mr. C and the Potential for Psychotic Transference. Mr. C, a forty-year-old transvestite, was referred for supervision for the charge of prostitution. At his intake interview, he showed many signs of borderline personality disorder, including abuse of alcohol and drugs, financial and emotional dependence on his mother, profound identity confusion, sadomasochistic sexual acting-out, acute spells of anxiety and depression, and, in relationships, extreme neediness and fear of abandonment coupled with fears of intimacy. In discussing his previous treatment experience, $\mathrm{C}$ related that he terminated his treatment because his psychiatrist "wanted to sleep with" him. After more discussion, the caseworker's impression was that $C$ was describing his experience of a psychotic transference and that his capacity to maintain a realistic treatment alliance would be easily overwhelmed by the paranoid and erotic transferences stimulated

22. Gloria Cunningham, "Social Work and Criminal Justice: New Directions in Practice," Federal Probation 44 (March 1980):64-69. in once-a-week sessions. So the treatment contract agreed on was that $\mathrm{C}$ and the caseworker were to meet every three weeks, with interim interviews and phone contacts if needed. The caseworker's approach with $C$ was ego-supportive and consisted primarily of empathic listening and problem solving.

In the course of his two years on supervision, $C$ was able to form a consistent treatment alliance with the worker. His progress was evident in several changes: He was able to join Alcoholics Anonymous, relinquish his addiction to drugs, move away from home and become self-supporting, separate from an abusive lover, and complete his education in data processing. He decided against a transsexual operation: "I want to be a man and function like a man." At termination, he planned to take steps to obtain further help through a gay counseling organization in his neighborhood.

\section{Right to Confidentiality, Potential for Violence}

The consensus of the literature on the predictability of violent behavior seems to be that violence cannot be predicted with any certainty. ${ }^{23}$ Yet forensic social workers and other mental health professionals are constantly called on to assess clients' risk to themselves or others. A factor that further complicates the worker's plan for acting on an assessment that danger is likely is that Illinois law ${ }^{24}$ explicitly states that violence must be "imminent." Clients who represent relatively constant threats to themselves or others, but who do not threaten "imminent" harm, are protected by their right to confidentiality. ${ }^{23}$ This means that unless the worker is convinced that the client's threats of violence are going to be acted upon "imminently," the client's disclosures cannot be shared with those threatened, and the worker cannot petition for client hospitalization. For example, a court psychiatrist decided against certifying a client of the Social Service Department and made the following distinction:

23. Joseph J. Cocozza and Henry J. Steadman, "Prediction in Psychiatry: An Example of Misplaced Confidence in Experts," Social Problems 25 (February 1978): 265-76; Daniel Schwartz, "Some Problems in Predicting Dangerousness," Psychiatric Quarterly 52 (Summer 1980): 79-83; Henry J. Steadman, "The Right Not to Be a False Positive: Problems in the Application of the Dangerous. ness Standard," Psychiatric Quarterly 52 (Summer 1980):84-99; and Saleem A. Shah, "Dangerousness and Civil Commitment of the Mentally Ill: Some Public Policy Considerations," American Journal of Psychiatry 132 (May 1975):501-05.

24. Illinois Revised Statutes-1981: Ch. 911/2, para. 811. 25. Ibid. 
This individual has an alcohol problem. He drinks to excess, and when he drinks he is prone to violence. On occasion he can flare up quite suddenly and act out in a violent fashion.... [The client is not] an immediate danger to others, but is seen as a chronically dangerous person. The likelihood of his committing significant acts of violence at some time in the future is very high. ${ }^{26}$

The forensic social worker who tries to establish a confidential therapeutic alliance with a client continually has to weigh the need to protect the client and the community from the client's violence against the client's right to confidentiality and the importance of fostering the client's trust. The issue is complex, since many clients' involvement with the law expresses a need for control they cannot themselves provide. If used with respect and care, the authority of the court can be invoked by the forensic social worker to strengthen the client's weak motive to get treatment and to improve impulse control.

Given the complex issues of confidentiality and imminent harm, the policy of the Social Service Department is that forensic social workers seek consultation when faced with these decisions. The role of the consultant at these times is to help the workers be free enough of anxiety to determine the client's potential for violence realistically. The following case illustrates how the forensic social work team of the Domestic Violence Program balanced these sensitive issues.

Mr. B's Alcoholism and Violence: Mr. B, a fortyfive-year-old black male, was referred to the Domestic Violence Program on a battery charge. When asked about the arrest incident, $B$ indicated that he had hit his common-law wife in the face with an empty wine bottle when he learned that she was seeing another man. B admitted that he had been drinking at the time of the incident. He and his wife, who had been together for eighteen years and had five children, separated at the time of the arrest. At referral, B was angry, depressed, and isolated. He was unemployed, had quit jobhunting, and seemed to lack any meaningful activities.

The worker's initial assessment was that B had a serious drinking problem. From the outset, B participated regularly in the group sessions of the

26. From the diagnosis made by court psychiatrist Stephen Cann, Psychiatric Institute, Circuit Court of Cook County, State of Illinois, November, 1982.
Domestic Violence Program. Although he consistently resisted the worker's referral for alcohol counseling, he became increasingly aware of the link between his alcohol abuse and his violence.

Shortly after referral, B spoke of being ridiculed and mentioned the possibility of burning down his wife's and his sister's house. The workers discussed the threats with their supervisor and concluded that imminent danger was unlikely. B had not planned a specific time for the arson, and he indicated that he did not want to harm his children, who were living with his wife. Eight weeks later, B mentioned that he had been drinking before the group meeting, and that he wanted to "get even" with his wife and her boyfriend. The worker's assessment was that, because B's threats did not include a specified action or time frame, imminent danger could not be ascertained with sufficient certainty to justify threatening the confidential relationship. Other considerations were that $B$ had ventilated his feelings and had calmed down during the course of the meeting and that he had indicated an awareness of the negative consequences of any violent actions. He had not acted on his earlier threat, or, to the knowledge of the workers, on any violent impulses since the arrest incident. In addition, informing the boyfriend of B's threats might have led to violent retaliation by the boyfriend.

However, B did become violent. At the next group meeting, B indicated that when he left the previous meeting, he had gotten drunk and had stabbed his wife's boyfriend with an ice pick. At this meeting, B threatened to kill his wife, her sister, and her boyfriend. After consultation, B's wife was called and the stabbing incident was confirmed. It was assessed that there was imminent danger and that B was likely to carry out his threats. Consequently, the worker advised B's wife, her sister, and her boyfriend of B's threats.

Violence was so endemic to B's environment that no criminal complaint was signed after the stabbing incident, and indeed, no one remarked on his violence until he did at the next group meeting. To respond to his violence, in addition to contacting the people B had threatened, the workers returned B's case to court and advised the court of the stabbing incident. The workers' assessment was that helping B to stop drinking was essential to his being able to control his violent behavior. Therefore, they requested that $B$ be ordered to attend alcohol counseling immediately and return to court in one month for a status report. The court followed the recommendations.

B was initially very angry at the workers for contacting his wife about his threats and for returning his case to court. He indicated that he felt that he could no longer be honest in the group and stated, "I thought what we say here is confiden- 
tial." When the workers explained that they had taken his threats very seriously, and informed him that they acted in order to assist him in taking control, he was less angry and seemed relieved.

B followed through with the referral for alcohol counseling, and after a month he quit drinking. The forensic social workers worked closely with the alcoholism counselor. During the last six months of B's participation in the Domestic Violence Program, he maintained sobriety and continued to attend alcohol counseling. After B completed group meetings, he met together with his forensic social workers and the alcohol counselor to discuss his progress and treatment plan. By termination, B had stopped making threats, had established new relationships in his alcohol counseling group, and had developed more self-confidence. He seemed invested in finding new activities that did not involve drinking. He was able to see his children again and had begun to seek employment.

\section{Use of Arrest Reports and Collaterals}

With some clients, a forensic social worker will not be able to act as an effective agent for change by seeing a client individually. In order to work on problems that precipitate the defendant's acting-out, the forensic social worker may need to work with others who are significantly involved with the client. In those cases in which the client's denial makes another offense more likely, the sensitive use of police reports and the participation of collaterals can help lessen the client's defensiveness.

In the following case, the worker was working with the defendant and his wife as the state child welfare agency was responding to the child's needs. However, the worker kept herself aware of the child's progress and care in order to step in and provide direction to the family or the agency as needed. In this case, the worker did keep the agency informed.

Mr. D's Troubled Marriage and Denial of Incest: Mr. D, a twenty-nine-year-old black employed male, was referred for supervision for the charge of contributing to the sexual delinquency of a child. The court mandated psychological counseling and ordered that he would only be permitted to remain in the family's apartment with his wife's permission. The worker saw $D$ individually for the first two meetings in order to gather a social history and gain an understanding of his past perceptions of the incest incident, as well as his current view of his domestic situation.

D's denial of his offense was so rigid that the worker referred to the police narrative of the defendant's sexual fondling of his daughter, as reported by his wife. D responded by saying, "If my stepdaughter said I did it, it must be true." The use of the arrest report thus elicited some minimal acknowledgment of the incident.

The worker was aware that denial, lack of responsibility for the incident, excessive drinking, and unrealistic expectations of marriage are common traits among child sexual abusers. Therefore the treatment alliance was broadened to include Mrs. $\mathrm{D}$, his thirty-year-old wife, to establish a reality base to effect change in the family. In addition, when Mrs. D took her eight-year-old daughter to a local hospital for medical attention and subsequent court proceedings, D was referred to a sexual abuse offender's program that met weekly. The forensic social worker coordinated services with this agency to monitor D's treatment progress.

In bimonthly sessions with the forensic social worker, the couple remained motivated and verbal, making counseling a productive experience. They were able to talk about the family mores and background, their courtship and decision to marry, their present marriage in the light of D's insecurity and jealousy, their needs and expectations for each other, and finally, the issue of D's alcoholism as a crucial factor in the sexual acting-out. Communication patterns and expression of feelings that had previously operated at a dysfunctional level improved, and husband and wife felt more understood by each other. D remarked to the worker that "you have really touched our lives and made a difference in how we deal with each other."

However, as the termination date for supervision approached, D had not openly admitted the incestuous incident in the group or the marital sessions. The worker also received an additional history from the state child welfare agency that indicated that the supervision charge was the third such incident reported. Consequently the forensic social worker conveyed to the client and his wife her plans to return the case to court to ask for a oneyear extension of the supervision and treatment order. Mrs. D became angry enough to confront her husband about his denial. Subsequently he was able to discuss the incest incidents with Mrs. D, the forensic social worker, and the group. The worker returned the case to court with documentation from both agencies. A one-year extension was granted for continuing treatment, and the D's have continued to make steady progress.

In cases such as incest, in which denial and distortion are prevalent, the use of objective evidence (social or legal documentation) and the involvement of a significant family member are imperative if treatment is to be successful. In this situation, the authority of the 
court was used to foster the client's motive to utilize treatment.

\section{A Working Alliance with Involuntary Clients}

Mental health practitioners often state that clients who enter treatment under duress of a court order cannot form a genuine treatment alliance. However, the forensic social worker often sees that court-ordered clients can form a treatment alliance, significantly improve their lives, and derive psychological benefits from treatment. For the alliance to occur, it is essential that the client's feelings of being "coerced" be recognized and worked through with the social worker ${ }^{27}$ and that the client has the experience of making an autonomous choice to obtain help. It is essential that the worker communicate empathy but at the same time help the client to understand that if he or she can utilize treatment to control behaviors, he or she will not be in the painful position of being coerced by the court.

Mr. V's Motivation for Treatment: Mr. V, a twentyeight-year-old white male, was referred for supervision because of repeated traffic offenses of driving without a license. He had a history of juvenile delinquency and had been severely abused by both parents, who were alcoholics. At his first interview he was acutely disorganized, his housing and income were unstable, and he admitted to suffering from grand mal epilepsy, which was untreated.

During the first session, $\mathrm{V}$ was able to verbalize some of his feelings about the counseling being "not my idea," but rather "the court's." In subsequent interviews, he was able to see that his reporting to and participating in counseling were choices he made to act in his own best interests.

27. Judith Gingolani, "Relationship Processes with Involuntary Clients: Issues and Options" (Paper presented at the Illinois Chapter of the National Association of Social Workers Meeting, October, 1982). Other authors have discussed the use of authority in casework, the function of coercion, and the treatment of reluctant or involuntary clients: Nathan Berman, Jack Purves, and Dorothy Cole, "Casework with Law Violators," Crime and Delinquency 7 (April 1961):137-47; Dale G. Hardman, "Authority in Casework-A Bread and Butter Theory," National Probation and Parole Association Journal v (July 1959):250-54; Dale G. Hardman, "Authority Is My Job," NPPA Journal (July 1957): Mangrum, "The Function of Coercive Casework in Corrections"; Allison D. Murdach, "Bargaining and Persuasion with Nonvoluntary Clients," Social Work 25 (November 1980):458-61; Gerald R. Tracey, "A Social Worker's Perspective on Social Work in Probation," Crime and Delinquency 7 (April 1961):131-36; and John Vriend and Wayne W. Dyer, "Counseling the Reluctant Client," Journal of Counseling Psychology 20 (May 1973):240-46.
He began to experience his alliance with the worker as reflecting an autonomous caretaking motive.

After four sessions, $V$ requested sessions on a more frequent, more intensive basis.

The forensic social worker and $\mathrm{V}$ agreed to a once-a-week treatment contract. At first there was a period during which $\mathrm{V}$ reacted to his efforts to get help and to his increased involvement with the forensic social worker by increased anxiety and confusion about appointment times. However, this reaction diminished, and he soon was able to keep his appointments regularly and to participate more actively in treatment.

After a year, $\mathbf{V}$ had made significant progress in many areas. He had found stable housing, received medical care on a regular basis for his epilepsy, and he admitted to and began to get help for his drinking problem. He obtained a divorce and started working part-time as a mechanic. He was able to experience improved impulse control, saying, "I feel less alone now" and "I haven't gotten into trouble because I know I have someone to talk with about my problems, instead of just getting mad or doing something stupid that gets me in trouble." After his court supervision terminated, $\mathrm{V}$ decided to continue treatment sessions with the forensic social worker.

V's statement illustrates a long-standing psychoanalytic maxim, "dissocial behavior can be an outlet for repressed emotion."28 Forensic social workers often see clients whose acting-out is precipitated by loneliness and the need to express emotions that have not been verbalized. As the clients experience a therapeutic alliance and can articulate their feelings, their need to act-out often subsides.

V's case also illustrates the importance of enough flexibility in agency policy so that the worker can respond to the treatment needs of defendants after the court order terminates. To break off a treatment relationship can be countertherapeutic if significant unfinished issues remain and if a transfer of therapists does not seem viable. The department provides for these cases through its "consultation" policy, so that clients can continue working with a caseworker, if necessary, following termination of the court order.

\section{Roles of the Forensic Social Worker}

Many of the clients the forensic social worker sees have been diagnosed as "antisocial" or labeled "resistant and untreatable" in ear-

28. Aichhorn, Wayward Youth, p. 5. 
lier contacts with mental health agencies. The clients tend to use defenses of projection and acting-out, which impedes their ability to verbalize their feelings and gain insight into themselves. Often they are openly paranoid about the social worker and the prospect of treatment. Their behavior is almost always offensive or threatening to society at large, and yet is ego-syntonic to the client. Because of all these factors, the clients often have not been able to form a treatment alliance or, when they have, they have "fallen through the cracks" because in other social service programs they were found too difficult or too unpleasant to work with. When these clients come before the court, judges and attorneys accurately perceive their needs for mental health care and thus refer these forfeited clients to forensic social workers. ${ }^{29}$ In working with such clients, the forensic social worker provides services to the court, the community, and the client in many different ways.

In bridging the mental health and criminal justice systems to serve forfeited clients, the worker often acts as a "transitional object" for these clients. If the client's positive transference is cultivated and some of the client's basic needs begin to be met, the client can begin to have the experience that treatment can be helpful and develop the capacity to form a treatment alliance. The alliance with the forensic social worker can then be transferred to the appropriate mental health agency for long-term psychiatric care. The following case exemplifies the many roles played by the forensic social worker in treating one case over two and one-half years. Proper treatment of the case necessitated that the worker be able to communicate with professionals in mental health and criminal justice while providing treatment.

Mr. F: A Forfeited Client: Mr. F was a twentyyear-old white male referred following a burglary charge. $F$ had broken into a neighbor's home to fix himself dinner after he had been left at home by his family for a weekend without funds or food. Shortly after the sentence to supervision, the severe family conflicts and organic and emotional pathol-

29. Whitmer, "The Development of Forensic Social Work." ogy of the client became obvious to the forensic social worker.

Almost immediately, conflicts between $F$ and his family escalated, and it appeared that $F$ was at risk of suicide. The forensic social worker referred F to the Court Psychiatric Institute, informing the institute of her diagnostic impressions, and $F$ was certified. He was transferred to a long-term state mental hospital and the forensic social worker coordinated services with F's therapist with the goal of facilitating F's eventual reintegration into the community. F's record and history were collected from juvenile probation, The Department of Children and Family Services, group homes, and mental hospitals.

To summarize F's history, he had been physically and sexually abused by his family and neighbors since early childhood. At twenty, he was functionally illiterate. A history of pedophilia, suicide attempts, substance abuse, and juvenile crimes attested to F's profound mental disturbance and poor impulse control. Intermittent and brief hospitalizations had culminated in unsuccessful placements and further arrests or self-destructive behaviors. Just before the burglary, Fs case had been reviewed in mental health court. He had been released in the custody of his family, and his case with the Department of Children and Family Services had been terminated because he was "resistant."

During his nine-month hospitalization, $F$ showed the capacity to respond to psychodynamic treatment. But within a month of his discharge, $F$ had run away from the halfway house and was living in the streets. After six weeks, he made contact with the forensic social worker. On investigation, the forensic social worker was informed that $F$ had been discharged without funds, food, shelter, or supportive services. Although his court case was terminated, $F$ requested services and was seen on a consultation basis, since he had no other supportive relationship that could provide professional care.

Although housing was arranged, F's condition was fragile. Shortly thereafter he was arrested for the charge of indecent liberties with a child. During the police investigation, $F$ became so frightened that he admitted to every imaginable aspect of a sexual crime. As a result, he was indicted for five Class $\mathrm{X}$ felonies and faced a possible prison sentence of sixty years.

F's reaction while awaiting trial was to become acutely anxious and suicidal and to provoke violent attacks from other inmates. The forensic social worker worked with the psychiatric team at the jail and provided crisis intervention treatment. $F$ was seen twice weekly throughout his incarceration pending trial. In addition, the forensic social 
worker contacted a skilled legal aid attorney who agreed to represent $F$. Another crucial aspect of the forensic social worker's role at this stage was to provide clinical data to Fs attorneys, the Court Psychiatric Institute, and a private psychiatrist regarding F's condition and his mental competency to stand trial.

After several months it became clear that there were no signs of physical injury to the complainant and that the complainant would not testify. After consultation with the state's attorneys, F's attorneys gave him a choice: to take the risk of standing trial or to plead guilty and accept a conditional discharge sentence. $F$ eventually decided to plead guilty and be sentenced to conditional discharge.

The forensic social worker located a residential treatment setting for $F$. To facilitate the referral process, the caseworker wrote a detailed psychosocial history that presented the antisocial behavior not as the problem itself, but as a symptom of a mixed personality disorder and a developmental disorder. With the leverage of the court system to motivate $F$ to adjust to the treatment facility, staff at the residential treatment facility were willing to interview F. He was accepted for placement. Based on the recommendation of the psychiatrist, the forensic social worker, and the attorneys, and given the assurance that $\mathrm{F}$ would reside in a structured setting and continue to participate in psychotherapy, the judge accepted F's plea and sentenced him to four years conditional discharge.

F was taken to the residential treatment home directly from court by his attorneys and the forensic social worker. The forensic social worker worked with $F$ individually and coordinated services with the staff at the halfway house to facilitate F's adjustment.

\section{New Directions}

A more assertive, streamlined approach to crisis intervention with actively psychotic defendants and specialized areas of competence are two new directions in forensic social work for the department.

A long-standing question in forensic social work has been how to facilitate the examination and commitment of the resistive psychotic client to a mental health facility that has the expertise and resources to provide long-term care. Protection of the community and the individual's need for in-patient treatment often has to be weighed against the individual's refusal to accept treatment. Rather than seek criminal litigation as the only solution to change antisocial behavior that is rooted in psychotic illness, the most effective and efficient means is through the mental health system. The qualified examiner role has developed as a way for the forensic social worker to direct a client to the mental health system using the authority of the local police and the courts. ${ }^{30}$

Domestic violence and substance abuse are client problems frequently encountered in clients by forensic social workers. The department has begun to provide specialized services in the area of domestic violence, a group treatment program ${ }^{31}$ targeted at the male batterer. The staff is increasingly aware of the prevalence of alcoholism as a contributing factor associated with crime, as well as the lack of treatment facilities for indigent, substance-abusing clients. ${ }^{32}$ The current goal is to increase staff competence in the assessment and treatment of substance abuse disorders. In addition, the department has developed a specialized program in community service $^{33}$ and is contemplating the development of special treatment programs in sexual abuse and theft. ${ }^{34}$

\section{Theory and Practice}

The clinical experience of forensic social workers at the Social Service Department of the Circuit Court of Cook County has been

30. Illinois Revised Statutes-1981: Ch. 91 1/2, para. 1-100 through 6-107. The forensic social worker in Illinois can utilize the Illinois Mental Health and Developmental Disabilities Code to route the psychotic defendant to psychiatric treatment by functioning as a qualified examiner. A qualified examiner is a person registered or certified with the State as a certified social worker [MSW] or as a registered psychiatric nurse [MA], with three years of clinical training and experience in evaluating and treating mental illness.

31. Gale A. Dreas, Dorothy Ignatov, and Thomas P. Brennan, "The Male Batterer: A Model Treatment Program for the Courts," Federal Probation xxxxvi (December 1982):50-55.

32. Bradley Googins, "Avoidance of the Alcoholic Client," Social Work 29 (March 1984):161-66.

33. Thomas P. Brennan and Leonard Mason, "Community Service: A Developing Concept," Federal Probation xxxxvii (June 1983):49-57.

34. A Retail Theft Program, initiated to provide education, guidance, and other intervention strategies, is sponsored by the Behavior Intervention Group, Rush-Presbyterian-St. Luke's Medical Center. See Charles Mount, "County to Expand Successful Shoplifting Counseling Program," Chicago Tribune, 29 Mar. 1984. 
integrated with a broad base of theory to provide a conceptual paradigm for the new, much-needed field of forensic social work. The individual forensic social worker, in integrating the polarities of empathic casework and the control and authority of the court, implements a practical link between mental health and criminal justice. By helping "forfeited" clients who fall between the cracks in the two systems, these workers provide a preventive and restorative service to a needy population of clients who, if left unserved, pose grave risks to themselves and to society.

In the course of working with highly resis- tive clients, forensic social workers can contribute to the development of theory and practice in the treatment of mentally ill and antisocial clients. Although there are obstacles to the growth and practice of forensic social work as a clinical specialty, the need to develop practical solutions to treat the forfeited client is imperative. Forensic social workers can begin to bridge the long-standing gap between criminal justice and mental health. It is hoped that, with the growth of forensic social work, a bridge can be built between criminal justice and mental health that can make both treatment and justice possible.

\section{Coming in Social Casework...}

- Helping Wives in Dual-Earner Families

- Clinical Judgments of Poor Clients

\section{- A Day Treatment Program for Adolescents}

These important articles and others of equal value will appear in the following issue of the journal. You owe it to yourself-and to the people you work with-to keep up with developments in the profession. Read Social Casework: The Journal of Contemporary Social Work. Subscribe now or renew your subscription. Use the coupon below for fast service.

Individual Rates: USA and possessions $\$ 27$ (one year), $\$ 51$ (two years); Canada $\$ 31$ (one year), $\$ 59$ (two years); all other countries $\$ 32$ (one year), $\$ 61$ (two years).

Institutions and Libraries: USA and possessions $\$ 40.50$ (one year), $\$ 77$ (two years); Canada $\$ 44.50$ (one year), $\$ 85$ (two years); all other countries $\$ 45.50$ (one year), $\$ 87$ (two years)

Social Casework, 11700 West Lake Park Dr., Mllwaukee, WI 53224

Enter my subscription for year(s). Check is enclosed or

Charge my: $\square$ Visa $\square$ MasterCard Account No.

Signature. Exp. Date

Name

Address

City/State/Zip 